\title{
PENERAPAN PROJECT BASED LEARNING DENGAN LESSON STUDY UNTUK MENINGKATKAN HASIL BELAJAR TEKNIK PEMESINAN
}

\author{
Bastian Rikardo Parhusip ${ }^{1}$, Bernadus Sentot Wijanarka ${ }^{2}$ \\ 1,2 Pendidikan Teknik Mesin Fakultas Teknik Universitas Negeri Yogyakarta \\ Email: bastianrikardo@gmail.com
}

\begin{abstract}
This study aims to: (1) promote students to become active and skillful, (2) improve students' knowledge, and (3) improve students' skills through the implementation of project-based learning (PjBL) by lesson study on milling machining subject. This research used quasi-experiment research method with one group pretest-posttest design. To test the hypothesis, data were analyzed using paired sample t-test incorporating Wilcoxon test technique aided with SPSS 20. The results show that: (1) lesson study promotes active and skilled students. It is observed that student activeness is above 90\% ("very active" category), (2) the lesson study improves students" knowledge. The wilcoxon calculation showed that $p$ or Sig. (2-tailed) was 0,000, which was smaller than the specified significance level of 0.05 ( $p$ or Sig. (2tailed) <0.05), (3) the PjBL also improves student skills, which is shown by the same Wilcoxon calculation result.
\end{abstract}

Keywords: practical learning, machining competence, learning activeness

\begin{abstract}
ABSTRAK
Penelitian ini bertujuan untuk: (1) mewujudkan peserta didik yang aktif dan terampil, (2) meningkatkan pengetahuan dan ketrampilan peserta didik melalui penerapan project based learning (PjBL) dengan lesson study pada mata pelajaran Teknik Pemesinan Frais. Penelitian ini menggunakan metode penelitian Quasi Experiment dengan desain One group pretest-postest design. Teknik analisis data yang digunakan untuk menguji hipotesis adalah paired sample t-test dengan menggunakan teknik Wilcoxon test dengan bantuan program SPSS 20. Hasil penelitian menunjukkan bahwa: (1) kegiatan lesson study dapat mewujudkan peserta didik yang aktif dan terampil. Hasil pengamatan menunjukkan bahwa keaktifan siswa berada di atas 90\% dan masuk dalam kategori sangat aktif, (2) penerapan PjBL dengan lesson study terbukti dapat meningkatkan hasil belajar pengetahuan siswa dan meningkatkan keterampilan siswa. Hal ini ditunjukkan dengan nilai p atau Sig. (2-tailed) baik pada pengetahuan maupun ketrampilan adalah 0.000, lebih kecil dari taraf signifikansi yang sudah ditentukan yaitu 0.05 (p atau Sig. (2tailed) < 0.05).
\end{abstract}

Kata kunci: pembelajaran praktik, kompetensi pemesinan, aktivitas pembelajaran.

\section{PENDAHULUAN}

Pendidikan adalah usaha sadar dan terencana untuk mewujudkan suasana belajar dan proses pembelajaran agar peserta didik secara aktif mengembangkan potensi dirinya untuk memiliki kekuatan spiritual keagamaan, pengendalian diri, kepribadian, kecerdasan, akhlak mulia, serta keterampilan yang diperlukan dirinya, masyarakat, bangsa dan Negara. Hakikat ini telah diamanahkan dalam Undang-Undang No 20 Tahun 2003 tentang Sistem Pendidikan Nasional. Konsep kurikulum yang telah dirancang oleh pemerintah harusnya mampu menghasilkan peserta didik atau lulusan yang kompeten di bidangnya masing-masing. Perkembangan kurikulum saat ini telah ditetapkan oleh pemerintah melalui Kementrian Pendidikan Dan Kebudayaan yang dikenal dengan sebutan Kurikulum 2013, adapun tujuan dari pemerintah melakukan pengembangan kurikulum ini adalah untuk memperbaiki sistem pendidikan sebelumnya yang dikenal dengan nama Kurikulum Tingkat Satuan Pendidikan (KTSP). 
Konsep kurikulum yang telah dirancang oleh pemerintah harus mampu menghasilkan peserta didik atau lulusan yang kompeten di bidangnya masing-masing. Penerapan Kurikulum Tingkat Satuan Pendidikan (KTSP) untuk meningkatkan kualitas/keterampilan peserta didik di SMK saat ini masih belum sesuai dengan tujuan kurikulum KTSP. Penyempurnaan atau perbaikan pendidikan menengah kejuruan untuk mengantisipasi kebutuhan dan tantangan masa depan perlu terus menerus dilakukan penyelarasan dengan perkembangan kebutuhan dunia kerja, perkembangan ilmu pengetahuan, teknologi, seni dan budaya.

Kualitas lulusan Sekolah Menengah Kejuruan (SMK) sangat ditentukan oleh perubahan /perkembangan ilmu pengetahuan dan teknologi. lulusan Sekolah Menengah Kejuruan (SMK) menyumbang tingkat pengangguran paling tinggi. Sebagian besar lulusan SMK tidak bisa diserap di lapangan kerja, karena kompetensi yang mereka miliki belum sesuai dengan tuntutan dunia kerja.

Perubahan kurikulum tingkat satuan pendidikan (KTSP) menjadi kurikulum 2013 yang tujuannya untuk memperbaiki sistem pendidikan yang lama mulai diterapkan di beberapa sekolah. Tujuan kurikulum 2013 dalam Permendikbud No 70 tahun 2013 adalah "untuk mempersiapkan manusia indonesia agar memiliki kemampuan hidup sebagai pribadi dan warga negara yang beriman, produktif, kreatif, inovatif, dan afektif serta mampu berkontribusi pada kehidupan bermasyarakat, berbangsa, bernegara, dan peradaban dunia”. Penerapan kurikulum 2013 masih banyak pihak yang Pro dan kontra dalam pengaplikasianya di sekolah. Permasalahan yang sampai tahun 2016 masih perlu diperbaiki adalah distribusi buku dan sosialisasi Kurikulum 2013 kepada guru-guru di sekolah. Perubahan kurikulum tingkat satuan pendidikan (KTSP) menjadi kurikulum 2013 yang tujuannya untuk memperbaiki sistem pendidikan yang lama mulai diterapkan di beberapa sekolah.
Penerapan kurikulum 2013 tidak dapat dijalankan secara maksimal di SMK. Dalam kondisi demikian tentu akan sangat berpengaruh terhadap hasil belajar dan hasil praktek siswa. Jika kondisi seperti ini tidak cepat ditanggulangi, maka sangat mungkin kualitas sekolah akan sangat menurun dan keberhasilan sekolah dalam menghasilkan lulusan yang baik, kompeten, dan mampu bersaing jauh dari yang diharapkan.

Di SMK Negeri 1 Sedayu masih ada dijumpai masalah dalam proses pelajaran praktik siswa, hasil wawancara dengan salah seorang guru mata pelajaran Teknik Pemesinan Frais di SMK Negeri 1 Sedayu, yang menjadi permasalahan mendasar dalam proses praktikum di bengkel yaitu minimnya sarana bengkel yang sangat berpengaruh terhadap hasil pengetahuan praktik siswa, seperti yang terlihat di SMK Negeri 1 Sedayu, jurusan Teknik Pemesinan memiliki 2 lab yaitu lab/bengkel praktik pemesinan dan lab gambar. Tingkat rasio jumlah peralatan praktik dan jumlah siswa masih perlu ditingkatkan. Hal ini agar pada saat pelajaran praktik semua siswa mendapat kesempatan untuk menggunakan atau mengoperasikan mesin.

Penerapan kurikulum 2013 pada mata pelajaran Teknik Pemesinan Frais selama ini di SMK Negeri 1 Sedayu masih cenderung beriorentasi pada guru sebagai sumber informasi dan pemindahan pengetahuan semata dengan metode mengajar yang tidak relevan dengan perkembangan teknologi, guru masih menggunakan strategi belajar konvensional tanpa melibatkan siswa untuk aktif saat proses belajar mengajar berlangsung. Hal inilah yang mengakibatkan kegagalan prestasi belajar praktik siswa, yang dibuktikan dengan perolehan nilai praktik siswa secara individu masih di bawah nilai Kriteria Ketuntasan Minimal yang ditetapkan (KKM=85). Pada tahun 2013 hasil praktik siswa kelas XII Teknik Pemesinan, ketuntasan KKM masih mencapai 70\%, tahun 2014 kelas XII Teknik Pemesinan ketuntasan KKM masih mencapai 68\%, dan pada tahun 2015 ketuntasan KKM masih 
mencapai 73\%. Demikian dengan ketuntasan secara klasikal dimana siswa yang memperoleh ketuntasan belum mencapai $75 \%$ atau nilai ratarata klasikal masih di bawah nilai kriteria ketuntasan minimal yang ditetapkan.

Pembelajaran praktik Pemesinan Frais sejauh ini hanya dilakukan secara kelompok, belum menerapkan cara pembelajaran tertentu seperti lesson study. Lesson Study merupakan suatu model pembinaan profesi pendidik (guru) melalui pengkajian pembelajaran secara kolaboratif dan berkelanjutan, berlandaskan prinsip-prinsip colleagues and mutual learning untuk membangun komunitas belajar (Sumar Hendayana dkk., 2007: 10). Artinya lesson study bukan metode atau strategi pembelajaran, namun melalui lesson study dapat diterapkan berbagai pembaharuan pembelajaran berdasarkan situasi, kondisi dan permasalahan yang dihadapi guru.

Berdasarkan kendala yang ada di SMK N 1 Sedayu dan implementasi kurikulum 2013 di SMK sekarang ini, untuk mengatasi permasalahan yang terjadi di atas perlu diterapkan proses pembelajaran dengan menggunakan pendekatan dan model yang ada di kurikulum 2013 yaitu project based learning/model pembelajaran berbasis proyek. Model pembelajaran berbasis proyek (project based learning) adalah sebuah model pembelajaran yang menggunakan proyek (kegiatan) sebagai inti pembelajaran (Hosnan, 2014: 319). Dalam kegiatan ini, siswa melakukan eksplorasi, penilaian, interpretasi, dan sintesis informasi untuk memperoleh berbagai hasil belajar (pengetahuan, keterampilan, dan sikap). Untuk mencapai kualitas yang telah dirancang dalam dokumen kurikulum, kegiatan pembelajaran perlu menggunakan prinsip yang (Wena, 2014): 1) berpusat pada peserta didik, 2) mengembangkan kreativitas peserta didik, 3) menciptakan kondisi menyenangkan dan menantang, 4) menyediakan pengalaman belajar yang beragam melalui penerapan strategi dan metode pembelajaran yang menyenangkan, kontekstual, efektif, efisien, dan bermakna.

Praktik Pemesinan Frais seharusnya dapat diterapkan menggunakan lesson study dengan memberikan seluas-luasnya kepada peserta didik untuk mengasah keterampilan dengan menggunakan model pembelajaran berbasis proyek. Pelaksanaan lesson study yang mampu memberi dampak pada keaktifan dan motivasi belajar peserta didik sesuai dengan tujuan Kurikulum 2013. Kegiatan lesson study yang menggunakan pendekatan dan model yang ditentukan pada Kurikulum 2013 diharapkan dapat mewujudkan peserta didik aktif, mandiri, dan terampil sehingga terbentuk budaya senang belajar, khususnya peserta didik SMK.

Tujuan dari penelitian ini adalah untuk mencari gambaran atau menganalisis: 1) terwujudnya peserta didik yang aktif dan terampil, 2) adanya peningkatan pengetahuan peserta didik pada mata pelajaran teknik pemesinan frais, dan 3) adanya peningkatan keterampilan peserta didik pada mata pelajaran teknik pemesinan frais.

\section{METODE}

Penelitian ini dilakukan dengan menggunakan metode Quasi Experiment (eksperimen semu) dan deskriptif kualitatif. Penelitian Kualitatif menurut Moleong (2007: 6) adalah "penelitian yang bermaksud untuk memahami fenomena tentang apa yang dialami oleh subjek penelitian, misalnya perilaku, persepsi, motivasi, tindakan, dan lain-lain. Secara holistik, dan dengan cara deskriptif dalam bentuk kata-kata dan bahasa, pada suatu konteks khusus yang alamiah dan dengan memanfaatkan berbagai metode alamiah”. Rancangan quasi experiment yang digunakan dalam penelitian ini adalah One group Pretest-postest design.

Tabel 1. One group pretest-posttest design

\begin{tabular}{lll}
\hline Pretest & Treatment & Posttest \\
\hline $\mathrm{T}_{1}$ & $\mathrm{X}$ & $\mathrm{T}_{2}$ \\
\hline
\end{tabular}


Desain penelitian quasi experiment dipilih atas pertimbangan situasi dan kondisi di lapangan, desain ini merupakan eksperimen yang mempunyai unsur pretest, perlakuan dan postest. Dalam penelitian ini digunakan satu kelompok subjek. Pertama dilakukan pengambilan hasil nilai awal, kemudian diberikan perlakuan dengan penerapan model pembelajaran project based learning dengan lesson study, setelah diberikan perlakuan maka dilakukan pengambilan hasil postest.

Penelitian ini dilakukan di kelas XII Jurusan Teknik Pemesinan SMK Negeri 1 Sedayu yang beralamat di Argomulyo, Sedayu, Bantul, Yogyakarta. Waktu Penelitian dilakukan pada semester ganjil tahun ajaran 2016/2017.

Subjek yang digunakan dalam penelitian ini adalah seluruh populasi yaitu kelas XII TPM jurusan teknik pemesinan SMK N 1 Sedayu. karena jumlah kelompok dalam populasi semuanya diambil sebagai sampel, maka penelitian ini adalah penelitian populasi (Arikunto 2013: 173).

Teknik pengumpulan data yang digunakan dalam penelitian ini adalah tes dan non tes. Tes digunakan untuk mengukur hasil belajar/praktik siswa, tes berupa Soal dan jobsheet. Sedangkan Non test yaitu berupa lembar pengamatan aktivitas pembelajaran lesson study, observasi aktivitas penilaian proses kerja praktik, penilaian hasil kerja dan dokumentasi.

Validitas yang digunakan di dalam penelitian ini adalah validitas konstruk (construct validity). Sukardi (2012: 33), menjelaskan bahwa validitas konstruk adalah sebuah instrumen yang dikonstruksi berdasarkan aspek-aspek yang akan diukur sesuai dengan teori yang relevan, kemudian selanjutnya dikonsultasikan kepada ahli (expert judgement). Validitas konstuk (construct validity) ini dilakukan dengan mengkonsultasikan instrumen kepada dosen pembimbing dan meminta pertimbangan dari para ahli (expert judgement) untuk diperiksa dan dievaluasi secara sistematis apakah item- item tersebut telah mewakili apa yang hendak diukur. Para ahli yang diminta pendapatnya antara lain ahli materi dan ahli media pembelajaran.

Teknik analisis data dalam penelitian ini menggunakan bantuan program SPSS 20 for windows. Penggunaan teknik analisis yang dimaksudkan untuk melihat peningkatan hasil belajar kognitif dan keterampilan siswa yang diajarkan dengan model pembelajaran project based learning dengan lesson study. Analisis data pada penelitian ini digunakan statistik nonparametrik. Statistik non-parametrik yang digunakan untuk menguji hipotesis adalah wilcoxon. Uji hipotesis dalam penelitian ini menggunakan analisis Uji beda, yaitu dengan menggunakan uji Paired sample T-Test, dengan teknik wilcoxon test.

\section{HASIL DAN PEMBAHASAN}

Penerapan lesson study dengan menggunakan model project based learning dapat meningkatkan aktifitas siswa dikelas, terbukti dengan hasil observasi para observer saat pembelajaran berlangsung, dan juga hasil angket yang diisi oleh siswa. 90\% siswa kelas XII memberikan pendapat bahwa penerapan Lesson Study dikelas sangat baik dan $10 \%$ siswa berpendapat bahwa penerapan lesson study di kelas Baik. Sebagian besar siswa merasa pembelajaran dengan menggunakan lesson study menjadi lebih menarik dan tertantang untuk lebih aktif di kelas dikarenakan siswa diberikan kebebasan untuk berkarya dan bekerja sesuai dengan keinginan siswa ataupun kesepakan kelompok, tanpa harus terbebani oleh aturan dan prosedur. Dari hasil wawancara dengan guru mata pelajaran Teknik Pemesinan Frais, penerapan project based learning dengan lesson study pada saat keterampilan sangat baik sekali karena untuk menyelesaikan satu materi atau pekerjaan waktu yang digunakan sangat singkat sekali berbeda dengan pembelajaran keterampilan sebelumnya. 
Dari hasil pengamatan observer pada saat proses pembelajaran berlangsung dan hasil pembahasan penerapan Lesson study di atas, maka dapat disimpulkan bahwa "Kegiatan lesson study yang menggunakan model pembelajaran Project based learning yang ditentukan pada Kurikulum 2013 dapat mewujudkan peserta didik aktif, mandiri, dan terampil. Hal ini dibuktikan dari hasil pengamatan observer sebagai berikut: (a) Kesiapan siswa selama mengikuti pelajaran keterampilan (menggunakan baju keterampilan dan K3) berjumlah 30 siswa (100\%). Hal ini menunjukkan bahwa aktivitas atau kesiapan siswa dalam mengikuti keterampilan masuk dalam kategori sangat aktif, (b) Siswa yang mengikuti pelajaran dengan antusias dan disiplin pada lesson study pertemuan pertama berjumlah 20 siswa (66,6\%) masuk dalam kategori cukup aktif, lesson study pertemuan kedua berjumlah 25 siswa (83\%) masuk dalam kategori aktif, lesson study pertemuan ketiga berjumlah 25 siswa (83\%) masuk dalam kategori aktif dan lesson study pertemuan keempat berjumlah 26 siswa (86\%). Hal ini menunjukkan bahwa aktivitas siswa dalam mengikuti pelajaran dengan antusias dan disiplin masuk dalam kategori sangat aktif, (c) Siswa yang ambil bagian dalam menyelesaikan tugas kelompok secara konsisten pada lesson study pertemuan pertama berjumlah 18 siswa (60\%) masuk dalam kategori cukup aktif, lesson study pertemuan kedua berjumlah 24 siswa (80\%) masuk dalam kategori aktif, lesson study pertemuan ketiga berjumlah 25 siswa (83\%) masuk dalam kategori aktif dan lesson study pertemuan keempat berjumlah 28 siswa (93\%). Hal ini menunjukkan bahwa aktivitas siswa yang ambil bagian dalam menyelesaikan tugas kelompok secara konsisten masuk dalam kategori sangat aktif, (d) Kegiatan siswa dalam menunjukkan adanya usaha bekerja sama dalam kegiatan kelompok pada lesson study pertemuan pertama berjumlah 18 siswa (60\%) masuk dalam kategori cukup aktif, lesson study pertemuan kedua berjumlah 24 siswa (80\%) masuk dalam kategori aktif, lesson study pertemuan ketiga berjumlah 28 siswa (93\%) masuk dalam kategori sangat aktif dan lesson study pertemuan keempat berjumlah 30 (100\%). Hal ini menunjukkan bahwa usaha bekerja sama dalam kegiatan kelompok siswa masuk dalam kategori sangat aktif, (e) Kegiatan siswa dalam usaha untuk bersikap toleran terhadap pemecahan masalah yang berbeda dan kreatif, pada lesson study pertemuan pertama berjumlah 15 siswa (50\%) masuk dalam kategori kurang aktif, lesson study pertemuan kedua berjumlah 20 siswa (66\%) masuk dalam kategori cukup aktif, lesson study pertemuan ketiga berjumlah 26 siswa (86\%) masuk dalam kategori sangat aktif dan lesson study pertemuan keempat berjumlah 26 siswa (86\%). Hal ini menunjukkan bahwa kegiatan siswa dalam usaha bersikap toleran dalam pemecahan masalah masuk dalam kategori sangat aktif, (f) Kegiatan siswa dalam memunculkan ide terhadap proses pemecahan masalah yang berbeda dan kreatif, pada lesson study pertemuan pertama berjumlah 10 siswa $(33,3 \%)$ masuk dalam kategori kurang aktif, lesson study pertemuan kedua berjumlah 22 siswa (73\%) masuk dalam kategori aktif, lesson study pertemuan ketiga berjumlah 28 siswa (93\%) masuk dalam kategori sangat aktif dan lesson study pertemuan keempat berjumlah 28 siswa (93\%). Hal ini menunjukkan bahwa kegiatan siswa dalam memunculkan ide terhadap pemecahan masalah yang berbeda dan kreatif masuk dalam kategori sangat aktif.

Hasil belajar pengetahuan siswa dapat dijelaskan sebagai berikut. Data yang dihasilkan dalam proses pembelajaran pengetahuan mata pelajaran Teknik Pemesinan Frais sebelum dilakukan penerapan project based learning dengan lesson study diperoleh rata-rata (mean) sebesar 77,33, skor tengah (median) 77,50, skor paling sering muncul (mode) 85, dan standard deviasi 6,915 dan data yang dihasilkan dalam proses pembelajaran mata pelajaran Teknik Pemesinan Frais setelah dilakukan penerapan project based learning dengan lesson study diperoleh rata-rata (mean) 
sebesar 84,67, skor tengah (median) 85,00, skor paling sering muncul (mode) 85, dan standard deviasi 7,184.

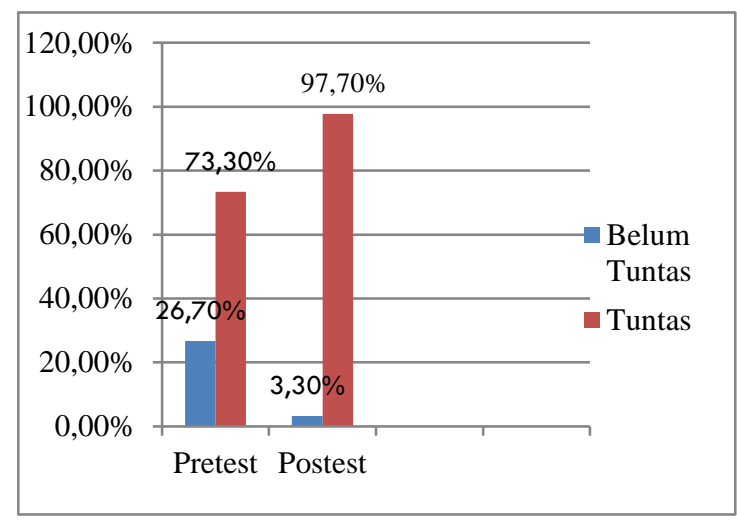

Gambar 1. Diagram ketuntasan pretest-postest pengetahuan

Gambar 1 menunjukkan bahwa hasil pretest siswa yang belum tuntas secara KKM berjumlah 8 orang dengan persentase 26,7\%, siswa yang lulus secara KKM berjumlah 22 orang dengan persentase 73,3\%. Dan hasil postest siswa diketahui bahwa siswa yang belum tuntas secara KKM berjumlah 1 siswa dengan presentase 3,3\%. Dan siswa yang tuntas secara KKM berjumlah 29 siswa dengan presentase $96,7 \%$.

Hasil analisi data hasil belajar pengetahuan menunjukkan perbedaan rata-rata hasil belajar pretest sebesar 77,33 sedangkan postest sebesar 84,67 , dari sampel berjumlah 30 siswa. Dari hasil uji hipotesis Wilcoxon menunjukkan bahwa nilai p atau Sig. (2-tailed) adalah 0.000 , lebih kecil dari taraf signifikansi yang sudah ditentukan yaitu 0.05 .

Nilai p atau Sig. (2tailed) $<0.05$ berdasarkan hasil penelitian dan pembahasan diatas dapat disimpulkan bahwa terdapat perbedaan yang signifikan antara hasil belajar pretest dan postest, Yang artinya dengan diterapkanya model Project based learning dengan lesson study ada peningkatan hasil belajar pengetahuan siswa.

Hasil belajar keterampilan siswa dapat dijelaskan sebagai berikut. Data yang dihasilkan dalam proses pembelajaran mata pelajaran Teknik Pemesinan Frais sebelum dilakukan penerapan Project based learning dengan lesson study diperoleh rata-rata (mean) sebesar 88,23, skor tengah (median) 88,00, skor paling sering muncul (mode) 87, dan standard deviasi 1,906 dan data yang dihasilkan dalam proses pembelajaran mata pelajaran Teknik Pemesinan Frais setelah dilakukan penerapan project based learning dengan lesson study diperoleh rata-rata (mean) sebesar 88,23, skor tengah (median) 88,00, skor paling sering muncul (mode) 87, dan standard deviasi 1,906.

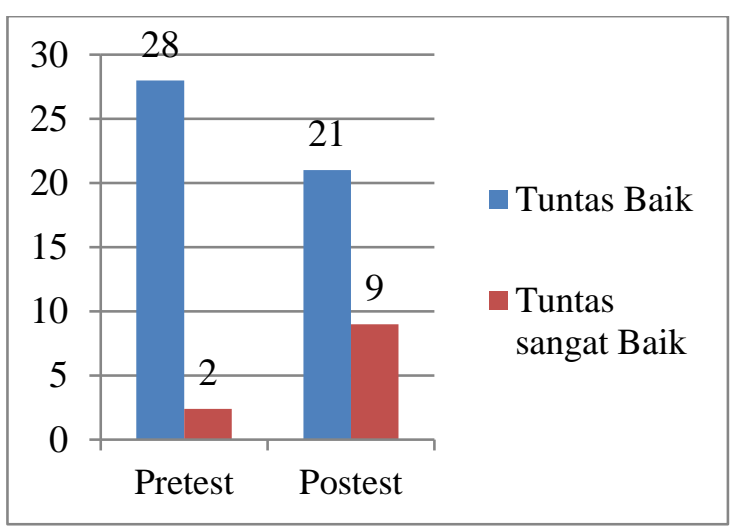

Gambar 2. Diagram ketuntasan pretest-postest keterampilan

Gambar 2 menunjukkan bahwa hasil belajar tertinggi pretest adalah nilai 92 sebanyak 2 siswa, skor terendah adalah nilai 85 sebanyak 2 siswa, dan skor paling sering muncul adalah nilai 87 sebanyak 7 siswa. Hasil belajar postest dari Gambar 2 diketahui bahwa skor tertinggi adalah nilai 94 sebanyak 4 siswa, skor terendah adalah 88 sebanyak 5 siswa dan nilai paling sering muncul adalah nilai 90 sebanyak 11 siswa.

Hasil analisis data hasil belajar keterampilan menunjukkan perbedaan rata-rata hasil belajar pretest sebesar 88,23 sedangkan postest sebesar 90,67 dari sampel berjumlah 30 siswa. Selanjutnya, hasil uji hipotesis wilcoxon menunjukkan bahwa nilai p atau Sig. (2-tailed) adalah 0.000 , lebih kecil dari taraf signifikansi yang sudah ditentukan yaitu 0.05 .

Nilai p atau Sig. (2tailed) $<0.05$ dari hasil penelitian dan pembahasan di atas maka dapat 
disimpulkan bahwa terdapat perbedaan yang signifikan antara hasil belajar pre-test dan post test, Yang artinya dengan diterapkanya model Project based learning dengan lesson study ada peningkatan hasil belajar keterampilan siswa.

Paparan hasil analisis data di atas membuktikan bahwa penerapan Project Based Learning dengan Lesson Study terbukti dapat meningkatkan hasil belajar pengetahuan dan keterampilan siswa, hasil ini relevan dengan hasi penelitian Ifa Muhimmatin tentang penerapan tugas peta konsep dalam PjBL untuk meningkatkan rerata pemahaman pengetahuan mahasiswa, dan terbukti bahwa Penerapan tugas peta konsep pada PjBL dapat meningkatkan rerata pemahaman konsep, motivasi, dan ketrampilan membuat produk. Relevan dengan penelitian Suparti yang meneliti tentang peningkatan hasil belajar siswa dengan penerapan project based learning.

\section{SIMPULAN}

Berdasarkan hasil analisis data dan pembahasan, maka dapat ditarik kesimpulan bahwa: (1) kegiatan lesson study yang menggunakan pendekatan dan model project based learning terbukti dapat mewujudkan peserta didik aktif dan terampil. (2) Terdapat peningkatan hasil belajar pengetahuan siswa yang diajarkan dengan model pembelajaran project based learning dengan lesson study. (3) Terdapat peningkatan hasil belajar keterampilan siswa yang diajarkan dengan Penerapan project based learning dengan lesson study.

Sebagai tindak lanjut dari hasil penelitian dan kesimpulan yang diperoleh, maka peneliti memberikan saran sebagai berikut: (1) Dalam pemilihan metode pembelajaran, diharapkan guru dapat memperhatikan karakteristik peserta didik. Memilih metode belajar yang berpusat pada siswa dan guru hanya terlibat sebagai fasilitator saja. Guru mata pelajaran Teknik Pemesinan Frais sebaiknya menggunakan dan menerapkan project based learning dengan lesson study, karena sudah terbukti dapat meningkatkan hasil belajar pengetahuan dan hasil keterampilan siswa. Akan tetapi, guru juga harus selalu mengarahkan dan memantau siswa agar aktif dan antusias dalam mengikuti pelajaran supaya tercapai hasil yang maksimal. (2) Siswa diharapkan lebih membagun aspek kerjasama kelompok dalam pemecahan masalah dan menggunakan waktu dengan semaksimal mungkin. (3) Sekolah seharusnya meyiapkan fasilitas keterampilan seperti kebutuhan mesin, alat dan bahan keterampilan secara menyeluruh guna meningkatkan potensi siswa dalam menghadapi dunia industri.

\section{DAFTAR RUJUKAN}

Arikunto, Suharsimi. (2013). Prosedur Penelitian suatu pendekatan praktik. Jakarta: PT. Rineka Cipta.

Hosnan. M (2014). Pendekatan saintifik dan kontekstual dalam pembelajaran abad 21. Kunci sukses implementasi kurikulum 2013.

Mendikbud. (2013). Peraturan menteri pendidikan dan kebudayaan Nomor 70 tahun 2013, Tentang Kerangka Dasar Dan Struktur Kurikulum SMK/MAK.

Moleong, J.L. (2007). Metode penelitian kualitatif. Edisi revisi. Bandung: PT. Remaja Rosdakarya.

Republik Indonesia. (2003). UndangUndang RI Nomor 20 tahun 2003 tentang sistem pendidikan nasional.

Sukardi. (2012). Metodelogi Penelitian Pendidikan: Kompetensi dan Praktiknya. Jakarta: PT. Bumi Aksara.

Sumar Hendayana, dkk. (2007). Lesson study: suatu strategi meningkatkan keprofesionalan pendidik (pengalaman IMSTEP-JICA). Bandung: UPI Press.

Wena, Made. (2014). Strategi pembelajaran Inovatif Kontemporer, suatu tinjauan konseptual operasional. Jakarta: PT. Bumi Aksara. 